\title{
Exploring the Discursive Construction of Obedience: An Analysis of Application Letters for the Position of Executioner in Hitler's Germany
}

\author{
Daniel Leisser $^{1}$ D $\cdot$ Katie Bray ${ }^{1} \cdot$ Anaruth Hernández $^{2} \cdot$ Doha Nasr $^{1}$
}

Accepted: 9 December 2020 / Published online: 10 February 2021

(c) The Author(s) 2021

\begin{abstract}
This article presents an empirical investigation into the construction of obedience in letters of applications mailed to National Socialist authorities for the position of executioner between the years 1933 and 1945. To this end, a corpus of 178 letters of application was compiled, annotated, and analyzed using the corpus analysis toolkits Antconc and Lancsbox. A quantitative and qualitative analysis of the corpus was conducted. The findings were related to and interpreted from the perspectives of applied legal linguistics, stylistics, and legal history. The project aims to explore the construction of a shared discourse of obedience and how this discourse is operative in the letters of application. Drawing on an explorative interdisciplinary framework, this project seeks to answer the following research questions: Is obedience a construct in applicants' letters of motivation? Which linguistic devices and discursive strategies are used by the executioners to express submission to officials of the National Socialist state? Are there variants of the construction of submission by applicants?
\end{abstract}

Keywords Third reich - Capital punishment - Critical discourse analysis . Executioners $\cdot$ Critical theory $\cdot$ Obedience $\cdot$ Application letter

Daniel Leisser

daniel.leisser@univie.ac.at

Katie Bray

katie.bray@oegrl.com

Anaruth Hernández

aherna30@ucsc.edu

Doha Nasr

doha.nasr@oegrl.com

1 Austrian Association for Legal Linguistics, Plenergasse 11, 1180 Vienna, Austria

2 University of California, 1156 High Street, Santa Cruz, CA 95064, USA 


\section{Introduction}

It is an obedience that is difficult because it stems from pure voluntarism and demands all the sacrifices that a man is able to make relative to personal pride, external honors, and many other things dear to him. It requires an unconditional commitment without the slightest hesitation as well as the execution of every order of the Führer even when an individual believes that he cannot personally accept it (Syllabus for the ideological education of the SS and the police) [30: 273].

Obedience and voluntarism are the backbones of a totalitarian state; those who command need those who obey, and vice versa. In 1941, Der Neue Brockhaus, a German-language encyclopedia, described obedience, inter alia, as an "expression of voluntary or enforced recognition of authority" [5: 177]. ${ }^{1}$ Hart has discussed obedience as a habit characterized by "a person or body of persons whose orders the great majority of the society habitually obey and who does not habitually obey any other person or persons" [5: 50]. However, such "habitual obedience" [21: 50] does not encompass forms of obedience which are largely driven by voluntarism or despair. Building on previous work by Semelin [43: 257] and Kressel [29: 168], we investigate unsolicited obedience, that is, a form of obedience that is neither the result of vertical exertion "by those who are invested with authority" [43: 257], nor directly explicable by peer pressure and/or conformism alone [29: 168]. This article aims to shed light on how such obedience as an expression of such voluntarism is constructed in letters of motivation written and dispatched to the justice system during the years of National Socialist (henceforth NS) rule. In these letters, applicants use language in various ways to request employment as executioners in the criminal justice system. In doing so, some applicants explicitly or implicitly express their willingness to serve the NS state. While not only executioners were involved in the killing of an increasingly large proportion of the population, it was this position to which people from a wide variety of economic, professional and social backgrounds applied, while other functions were held more by persons close to the state, often with a legal background. Therefore, dealing with letters of application for this position allows us to analyze unsolicited obedience as a phenomenon arising in different social spheres and contexts. Within the field of critical discourse analysis (henceforth CDA), texts such as application letters are considered a manifestation of such social action that is, in turn, determined by social structure [55]. One area of inquiry within CDA on which we are building in this article is concerned with the relationship between discourse and power in NS [39]. Following Reisigl [39], and Wodak and Meyer [55], the theoretical basis of this study is located within the field of critical discourse studies generally and the discourse-historical approach (henceforth DHA) specifically. The main objective of our study is neither to provide an exhaustive

\footnotetext{
1 Original: G[ehorsam]. ist Ausdruck freiwilliger oder erzwungener Anerkennung einer $\rightarrow$ Autorität und Voraussetzung aller Erziehung.
} 
investigation into authoritarian language use nor to contribute a lexicographic presentation of historical language use. We rather seek to bring up for discussion our analysis of a highly conventionalized genre, i.e. letters of application, and the discursive practices and power relations formed and found within them, as exemplified by the requests made to the authorities. In terms of our understanding of a critical analysis, we intend to express that we do not merely adopt a descriptive stance on language use. In addition to describing language use, we present an analysis and interpretation of language with a view to giving a critique of the social phenomena of obedience and submission as, in our view, largely evident in the texts under investigation. The following three research questions are at the basis of our inquiry:

(1) Is obedience a construct in the executioners' letters of motivation?

(2) Which linguistic devices and discursive strategies are used by the applicants to express their submission to officials of the NS state?

(3) Are there variants of the construction of submission by applicants?

We argue that a critical perspective on the operations of ideology in totalitarian systems is a prerequisite for uncovering the traces ideology leaves behind in texts, historical and contemporary. To our knowledge, a systematic linguistic analysis of application letters for the position of executioner in NS Germany has not been undertaken so far. The ongoing, though implicitly led, discussion on the notational distinction between analysis and interpretation of language use (see $[14,53])$ should not be ignored, but rather made an exercise of self-reflection on our own research practices and viewpoints. Before the presentation of the empirical study, it is necessary to specify the key concepts and definitions underlying the theoretical framework of the article. We largely draw on and apply Reisigl and Wodak's terminology [32, 37], which we use as follows for the purposes of this study. When we refer to "ideology", we understand it to be a tendentiously one-sided world view that is constructed of "related mental representations, convictions, opinions, attitudes and evaluations" [55: 88], which we assume to be shared by all agents who belong to a specific social group. We use the term "power" to express a communicative and factual asymmetry in the social relationship between the actors involved. This asymmetry is usually a result of the interpersonal positioning or the social groups to which the actors belong.

We use the term "discourse" to refer to "a cluster of context-dependent semiotic practices that are situated within specific fields of social action" [55: 89] and that is "socially constituted and socially constitutive" [55: 89]. Texts, in contrast, we assume to be individual parts of one or more discourses that "make speech acts durable over time", in doing so "bridging two dilated speech situations" [55: 89]. When considering the case of application letters under investigation, this is particularly relevant, since the author's, the addressee's and the researchers' interpretation of texts is heavily influenced by the temporal and spatial distance between speech production and speech reception as events of delayed communication. Our understanding of text is linked to the notion of context as the 
"immediate, language internal co-text and co-discourse regards thematic and syntactic coherences, lexical solidarities, collocations, connotations, implications, presuppositions and local interactive processes" [39: 53]. However, in the light of an analysis of texts created during the time of NS, it is imperative also to take into account what Reisigl refers as to the meso-level and macro-level of context, i.e. "the broader sociopolitical and historical context" [39: 53] which, in turn, requires the researcher to investigate the "fields of action and the history of the discursive event[s] as well as of discourse topics" [38: 157]. In other words, a merely descriptive account of various linguistic features found in the letters of application is insufficient if the research objective is an analysis of the intertextual and interdiscursive references in and discourses operative across the texts. Here we follow Fairclough's definition of genre as "a socially ratified way of using language in connection with a particular type of social activity" [13: 14]. In this sense, the socially ratified language use of applicants is a result of all social norms underlying an application process.

A terminological and theoretical distinction ought to be made between the notions of intertextuality and interdiscursivity, as presented by Reisigl and Wodak $[34,37]$. While "intertextuality" refers to the connection between texts, "interdiscursivity" means the potential of discourses to be linked to one another. For instance, the discourse on the death penalty in NS may frequently refer to topics or subtopics encoded in other discourses, such as that of antisemitism, racism and dehumanization, as well as so-called hereditary health (Erbgesundheit). We use the term "field of action" [18] for "a segment of social reality which constitutes a (partial) 'frame' of a discourse" [37: 90] with a particular focus on the application process itself. We assume that depending on the field of action "different functions of discursive practices" [55: 90] are required and defined. While to most contemporaries the act of applying for the position of executioner might appear most disconcerting, it should be acknowledged that the application process in NS Germany might have followed the same, or at least very similar social scripts as those operative in related contexts today, e.g. the advertisement of eight executioner positions in the Kingdom of Saudi Arabia in 2015 [46]. Due to space limitations, a comparative analysis of NS application letters and contemporary texts is not possible here, but is recommended for future research.

As for our understanding of the ideology of obedience, the actors involved and the interactional roles incorporated by them, we follow Spitzmüller and Warnke's multi-layered model of analysis (DIMEAN) [44]. Spitzmüller and Warnke assume the existence of two layers of analysis, i.e. the intratextual level (word/proposition/ text-oriented analyses) and the transtextual layer (discourse-oriented analysis). The transtextual layer of analysis has been described as the "plane of collective knowledge" [28: 11], which the analyst can reconstruct by shedding light on systematic linguistic practice. In order to lay bare "schemata, frames, and scripts, [...] metaphors, lexis and arguments" [28: 11] in discourse analysis, corpus analysis constitutes a fruitful and most certainly essential method. However, the intratextual and the transtextual level cannot exist without the agent layer that functions as a platform of mediation, i.e. it "capture[s] how discursive practices are shaped by rules and roles of interaction, but at the same time shape these rules and roles" [28: 11]. 
The present inquiry follows a five-part structure. Section 2 focuses on the historical legal context of the role of executioners in NS. Section 3 describes the corpus data, the process of corpus construction, the corpus design, and the metadata available for analysis. In Sect. 4, a stylistic analysis of 100 randomly selected corpus files is presented, with a view to providing a classification of the application letters. Section 5 contains a quantitative and qualitative analysis of requests made by applicants to NS authorities. Section 6 discusses various insights gained throughout the project, such as the fruitfulness of interdisciplinarity, the accessibility of sensitive historical language data, and the epistemological challenges in analyzing obedience and/or submission in language use as a social practice.

\section{Historical Legal Context: the Law, the Agents and Capital Punishment in Hitler's Germany}

The attempt to discuss the legal position of executioners in the 20th century comes accompanied by two main challenges. First, there is a lack of sources attestable, due to the anonymization of executioners and the order to keep the "strictest secrecy" [40: §4] regarding their profession. Second, written rules, e.g. laws, were inconsistent from village to village for a long time. What can be concluded from the sources available is that the profession of executioner enjoyed an ambivalent reputation in the NS state. This is also consistent with the fact that the state did not have a very great interest in making much known about the executioners. Their names as well as their identity were kept anonymous, since 1937 at the latest [23: 29]. In the documents they appear as 'judicial clerks' or 'judicial assistants'. Sometimes they were also given aliases. Their obligation to maintain 'strictest silence' about their work also contributes to the scant traceability of their professional life [40: $\$ 4$ ]. Therefore, written sources do not provide much information about them. The only accessible official correspondence addressing the profession of executioner is found in the state archives and the Federal Archives in Berlin. This effected lack of knowledge goes in line with a growing tendency towards discretion in the process of the execution of the death penalty in general by that time [12: 413-420, 23: 51]. Being a public trial, which 12 witnesses had to attend according to the rules of the Weimar Republic, it was gradually turned into a trial under strict secrecy, in which from 1939 only the executioner, three of his assistants, a doctor, a clergyman and a representative of the public prosecutor's office and the prison were allowed [23: 74].

Before 1937, the working conditions of executioners and thus also the contracts concluded with them were not uniformly regulated by the NS state. Just as the execution of the death penalty and the methods to be applied remained a matter of the countries (Länder) in the first years of NS rule, the executioners were also subject to the control of the regional judicial authorities [23: 52]. Still, although their task was to execute criminal law, in most cases they were not employed or part of the judicial system. Instead, they were self-employed and their working conditions varied from place to place. This manifests itself impressively when it comes to the conditions of their payment. Although all executioners were paid per execution undertaken, the amount of the remuneration received varied greatly. In addition, not every 
executioner enjoyed a fixed annual salary [7: 66, 7: 86]. Furthermore, the executioners' economic situation was additionally burdened by the fact that they, initially out of a perceived practical necessity, with the consent of the authorities and later on by legal order had to employ two or three assistants as freelancers [23: 70]. As a result, for some, the profession of executioner was indeed financially rewarding, while for others the payment was so scanty that it was not enough to secure their livelihood and, consequently, they needed state support [48: 30]. This is especially relevant since executions usually did not take place very often until the start of the expansion of the death penalty in 1933. Therefore, since the time of the Weimar Republic, executioners were often dependent on other professions in order to cover their subsistence. As early as the 19th century, their secondary activities can be well derived from other sources. Often, they took over 'less pleasant communal services' as bordell landlords, cleaners of cesspools, or other orderly and health police tasks. Many of them were present in the profession of renderers (Abdeckereiwesen). Some of them were veterinarians, gynaecologists, surgeons and psychiatrists [22: 352]. The relationship between the profession of executioner and that of doctor was well known and the subject of unusually open discussion and critical reflection. For instance, it is noted how doctors working as executioners would use their position to give their sons, who they enabled to study medicine, an insight into human anatomy that would otherwise not be possible [22: 353]. However, some professions had to be given up by executioners, being civil servants. For instance, Vienna's previous Austro-Hungarian executioner, Josef Lang, had to give up his established coffeehouse business after his official activity was disclosed.

The mentioned lack of posts started to change with the increase of executions in 1933, due to the expansion of the death penalty under the NS regime. Already at the start of the Second World War in 1939, the number of killings had reached a new peak with 219, as compared to 64 in 1933 [12: 774]. Still, although new places of execution had been installed in various places of the NS state, so that new vacancies would be the anticipated consequence, unsolicited applications were rather rejected.

Neither in the Weimar Republic nor in the NS state is there any precise information on criteria for eligibility as an executioner [23: 52]. In the Weimar Republic they mostly came from so-called dynasties of executioners, in which their ancestors had already exercised the same profession. Therefore, the examination of the qualification was not based on individual skills but on family descent. A well-known example would be Johann Reichhart, who descended from a Bavarian knacker and executioner lineage and took over the office from his uncle Franz Xaver Reichhart [11: 10, 19: 64].

Nevertheless, this changed around 1940, as NS Germany abolished this tradition and started appointing "non-professional" executioners as well. There were, however, no official public documents containing explicit requirements and criteria for the appointment as an executioner [23: 53]. Still, the correspondence between the authorities involved allows for the reconstruction of certain criteria. A preference for individuals with the following characteristics can be observed. Besides having no criminal record, they should be politically unscrupulous, which is also recognizable in a letter of reply from the chief public prosecutor of Stettin to a letter of application: "According to the information just given [...] the butcher [N.N.] has a good 
reputation; he has never been politically active and has managed himself well. In all other respects as well, [N.N.] should also be suitable for the job of an executioner" [17: 220, authors' translation]. Linguistic proficiency and physical strength seem to have been important qualities [17: 222, 17: 225].

In general, applicants were required to have an unobtrusive lifestyle. Having an alcohol problem or a tendency towards incompetence, outbursts of anger or violence or having existence-threatening debts seem to have been examples of reasons for the rejection of applications. Similar reasons for exclusion applied to potential assistants [17: 205]. A considerable number of applicants might have also been rejected because of their stated motives, which the authorities regarded as questionable, although they were very much in line with the NS ideology. In any case, an ordinance was issued in 1937 prohibiting the forwarding of these applications and prescribing an automatic rejection by the offices contacted. It remained in force until 1943 [26].

Although in some sources a proximity to the Nazi Party (henceforth NSDAP) was regarded as positive, albeit not of great importance, other sources show that the membership of an executioner would be rather undesirable. This would be supported by the fact that the Nazi regime refrained from tying the executioners directly to the state by permanent employment. Even in the case of Johann Reichhart, who actually was a member of the NSDAP, no reference to his membership can be found in the documents of the justice administration [23: 68].

The attempt to prohibit any obvious proximity of executioners to the NS regime is also well illustrated by the fact that the German salute to the attending public prosecutor before and after the execution at the place of execution was prohibited after the "Guidelines for Executioners" had been changed [23: 52, 8: 117] and displaying the Hitler salute was even punished with dismissal if the death penalty was being carried out. This goes in line with the traditional social ostracism of this profession [23: 68].

A critical attitude towards Marxism and communism and a positive basic attitude towards the NS state seem to have been sufficient for employment if the other criteria were met. Conversely, being a supporter of the Hitler movement did not prevent dismissal, if there was a reason for it [19: 245]. The descent or acquaintance of experienced executioners weighed more heavily. That is particularly evident in the example of Alois Weiß, who was expelled from the NSDAP for his critical remarks on corruption in the party system but was still accepted as an executioner's assistant and later as an executioner in Prague, because the executioner Johann Reichhart knew him and asked him to work as such [26].

Before 1937, the practical rules for executioners were not regulated or clearly defined across the board. However, the following tasks resulted from the practical exercise of their profession: execution of the death penalty, coercion of confession by torture, execution of corporal punishment and punishment of honour, as well as other unpleasant tasks.

In 1935, the Ministry of Justice undertook to harmonize the rules for the organization of executioners and the methods of execution [23: 60]. These efforts culminated in 1937 in the so-called new "Guidelines for Executioners", which were enforced since 1.8.1937 and were ultimately strongly oriented on the earlier treaties with 
Prussian executioners of the Weimar Republic, and even adopted their wording in some sections [23: 70]. The following areas were explicitly regulated and standardized in eleven sections: the contractual arrangement of the employment relationship, the tasks of the executioner, salaries, rules concerning the process of the execution, standards of conduct. Parts of it laid down rules that had already been established in practice but were not written down. Other parts regulated areas that had previously been open to question, down to the last detail.

What remained unregulated were the requirements for employment as an executioner or as an assistant, and the reasons for dismissal. The former was laid down in general terms with regard to assistants in a circular of the Ministry of Justice (Reichsjustizministerium). Only persons "who are reliable and of good repute and against whom there are no objections in political terms" [6: 222] $]^{2}$ should be admitted as such. The latter continues to be derivable only from jurisdiction: Reasons for dismissal included displaying the Hitler salute or Hitler calls in the execution room [12: 802], more than one chop to the head of the sentenced person (summary dismissal), often on the grounds that the executioner "no longer possessed the necessary freshness" [17: 4596], ${ }^{3}$ alcoholism and "financial irregularities" [23: 59]. ${ }^{4}$

For the first time the tasks of the executioner were now precisely described. Sect. ion 1 of the Guidelines states: "The task of the executioner is to carry out the death penalty by beheading or hanging at the request of the judicial authorities throughout the entire territory of the Reich [...]" [51: 54]. This regulation is specified in Sect. 6, which defines the competencies of the executioner within the execution process: Before each execution he should check the execution equipment for its usability, after the execution he should clean the execution equipment and the place of execution with the equipment provided to him by the penal institution, and he should coffin the executed person [23: 69].

In Sect. 4 of the Guidelines, the duty of the executioners to keep 'strictest silence' about their activity was legally established. Section 5 not only standardized the permissible number of executioner's assistants to three, but also prescribed them "good conduct" and "appropriate clothing", for which the executioner should be responsible [51: 54]. The subsequent sections dealt almost exclusively with the payment of the executioner, which was now standardized and regulated in great detail. The reason for this uniform and very detailed regulation of payment was that only three executioners should be assigned for the whole state. Consequently, they would not only carry out executions at their place of residence, but also travel for this purpose [23: 70]. In the Guidelines, executioners were finally also expressly allowed to continue to pursue a civil profession. The administration of justice was granted the right to terminate the contract at any time with a further six months' obligation to pay the fixed salary. In return, the executioner should be entitled to a three-month termination period [23: 70].

\footnotetext{
2 Bundesarchiv Berlin, 3001/21232, Blatt 222.

3 Original: "nicht mehr die erforderliche Frische", In: Letter of the Oberstaatsanwalt of Stetting, in: Geheimes Preuß. Staatsarchiv, I. HA Rep. 84a Justizministerium Nr. 4596: Schreiben vom 27.8.1934.

4 Original: "finanzielle Unregelmäßigkeiten": Hillenbrand, Berufswunsch, 59.
} 
Authorities attached great importance to an execution process that was as timeefficient as possible [12: 397]. This can be derived from the ideologically driven discussions between jurists and authorities of the NS state as well as letters of authorities addressing the question of the method of execution to be applied and emphasizing the need to be regarded as 'civilized' and 'progressive' by the outside world [9: 119]. Some of the applicants explicitly expressed their awareness of this in their letters, suggesting methods, perhaps with the aim of displaying their knowledge in this regard.

Before, criminal law only regulated the method of execution in one section, $\S 13$ RStGB 1935, which stipulated that an "execution" was to be carried out "by beheading" [36: §13]. ${ }^{6}$ Neither the preparation and follow-up of the execution nor the method of execution itself were legally regulated. Since the execution was otherwise considered a matter of the states, each of them used different methods of decapitation. For instance, the northern states of the German Empire used the hand axe (e.g. Prussia), while Bavaria and Saxony used guillotines. This changed on 28.12.1936 with a decree by Adolf Hitler stating that the death penalty in the NS state in cases of decapitation could only be carried out with the guillotine [36, 9: 179]. ${ }^{7}$

The intention of a short and efficient procedure also manifests itself in the renunciation of ceremonial rituals and speeches, with which in the $19^{\text {th }}$ century and earlier the general public was taken into account and which should now be prevented as far as possible [12: 397-398]. A good picture of how quickly, impersonally and bluntly such procedures took place in the NS state is shown by the report of a pastor of the Vienna Regional Court, one of the few people still allowed to attend the execution because of their profession:

The president: 'What's your name?'

The man in chains gives his name.

The president: 'You were sentenced to death for preparing to commit high treason. A pardon was not given. The sentence will now be carried out.'

With this question and the following three sentences, the brief formality of every execution was completed. Standing behind a desk, the People's Court had awaited the condemned man in a simple room. Nothing indicated that it already was the antechamber of death. The condemned man, flanked by two guards, had entered through a small black iron door. The eye-catcher for him was the president. So, he could not see that six men in black had come out from behind a curtain and stood behind him. The keyword was: "The sentence will now be carried out!" A hand was placed from behind over the victim's eyes, from the left and the right strong hands grabbed on, at a run, the curtain

\footnotetext{
${ }^{5}$ For instance (authors' translation): "It will take about $20 \mathrm{~s}$ less from the handing over to the executioner to the falling of the head": Bundesarchiv Berlin R3001/21314, Blatt $119 \mathrm{ff}$.

6 Original: "durch Enthauptung zu vollstrecken”: §13 RStGB 1935 (Germany).

7 Original: "Ist die Todesstrafe durch Enthaupten zu vollziehen, so ist das Fallbeil anzuwenden": In: Bundesarchiv Berlin R3001/21314, Blatt 179.
} 
Table 1 Sociodemographic characteristics self-disclosed by applicants

\begin{tabular}{lcr}
\hline Characteristic & Letters of Application $n$ & $\%$ \\
\hline Age & 120 & 67.4 \\
$20-29$ & 33 & 18.5 \\
$30-39$ & 42 & 23.6 \\
$40-49$ & 31 & 17.4 \\
$50-59$ & 12 & 6.7 \\
$60-69$ & 2 & 1.1 \\
Marital status & 50 & 28.1 \\
Unmarried & 4 & 2.2 \\
Married & 44 & 24.7 \\
Divorced & 2 & 1.1 \\
Children & 35 & 19.7 \\
Employment & 119 & 66.9 \\
Unemployed & 18 & 10.1 \\
Employed & 95 & 53.4 \\
Retired & 6 & 3.4 \\
NSDAP & 35 & 19.7 \\
\hline
\end{tabular}

was quickly pushed aside, we went through an open door into a laundry roomlike adjacent room, and immediately the dull thud of the falling guillotine echoed through the courtroom and far through the corridor of the Armsünder wing. On one evening I had heard the phrase 'The sentence will now be carried out' forty times" [41: 29, authors' translation].

Whether and to what extent applicants during their solicitation were fully aware of these impressions, which not only awaited them but which they themselves, if selected, would bring about, might, at least to a certain extent, be perceived from their letters of application. While one applicant explicitly states that he possesses the 'cold-bloodedness' necessary for the position, another claims to have witnessed executions before and therefore considers himself suitable for the position. Other applicants' expression of hatred, distress, as well as other not explicitly stated reasons seem to outweigh a potentially arising concern of being active agents in this process of judicially sanctioned homicide.

Due to space limitations the historical legal analysis must be limited to the context provided in this section. In the following section, the corpus data, the process of corpus construction, the corpus design, and the metadata available for analysis are described.

\section{Method: Corpus Construction and Design}

In this section the corpus design and the process of corpus construction is presented.

To conduct an analysis of the discourse of obedience in the NS state, the Corpus of NS Application Letters (henceforth CNSAL) was compiled between September 
2019 and August 2020. The corpus contains 178 letters received by the Nazi state between the years of 1933 to 1945. The CNSAL consists of 39,600 tokens and 5,070 types, with the longest application amounting to 984 tokens, and the shortest application only showing 30 tokens. The applicants vary in terms of their age, profession, and social class. The data was first analyzed regarding the applicant's age, gender, nationality, education, profession and employment status, NSDAP membership, religious affiliation, married status, and whether the applicants had children. The distribution of applicants' self-disclosed demographic data is shown in Table 1.

The average applicant constructs himself to be male, married, approximately 37 years old, not a member of the NSDAP or of another NS organization, and without any religious affiliation disclosed in their letter.

It is essential to acknowledge that this corpus diverges from 'traditional' corpora, and to clarify the considerations impacting the process of corpus construction. Nelson highlights that one of the propositions initially made by Halliday was for "the necessity of a corpus of around twenty million words" [33: 55]. To elaborate on this practice, it was thought that a corpus of this size would be the most helpful in linguistic research when the linguistic phenomena one seeks to investigate is about the lexis of the language. Moon argues in support that "[t]his kind of information is best obtained from a large reference corpus (ideally, at least fifty million words)" [32: 197]. Nelson further reflects "corpora that have been used for lexicographical purposes - looking at the whole language - have, perhaps by necessity, always been created to be as large as possible" [33: 55]. We can then summarize that larger corpora effectively serve the purpose to investigate "general linguistic phenomena" [27: 71]. As the claims of our study are limited to being representative of, at best, the speakers of German who wrote these letters in this historic period, and only contains written data, we explicitly abstain from asserting that obedience exists within the semantics of the letters themselves. The size of the corpus is one of the limiting factors that prevent us from positively being able to make this assertion through a corpus linguistics lens.

However, it no longer appears necessary for a corpus to contain twenty million words [33: 55]; rather it has become acceptable to work with more specialized and smaller corpora, such as the corpus in this study. For practical purposes, we apply Toriida's definition of a corpus as "a collection of sampled texts, written or spoken, in machine readable form which may be annotated with various forms of linguistic information" [49: 87], as originally proposed by Xiao, McEnery \& Tono [56]. We rely on this definition and move away from the lexicographical focused one that could be considered more typical of corpus linguistics, as this is a study primarily focusing on a contribution through the field of discourse analysis.

Corpus linguistics seeks to provide an observable empirical approach to data, allowing for a more complete exploration of scientific claims within itself, as well as other sub-fields of linguistics such as CDA. The various functions of computer software, and more specifically programming languages, render data within documents visible and of a reportable nature, which in turn produces clarity for the scientific community.

The historical context of the letters suggests a high degree of authenticity of the data. For all intents and purposes the data in this study can be considered a historic 


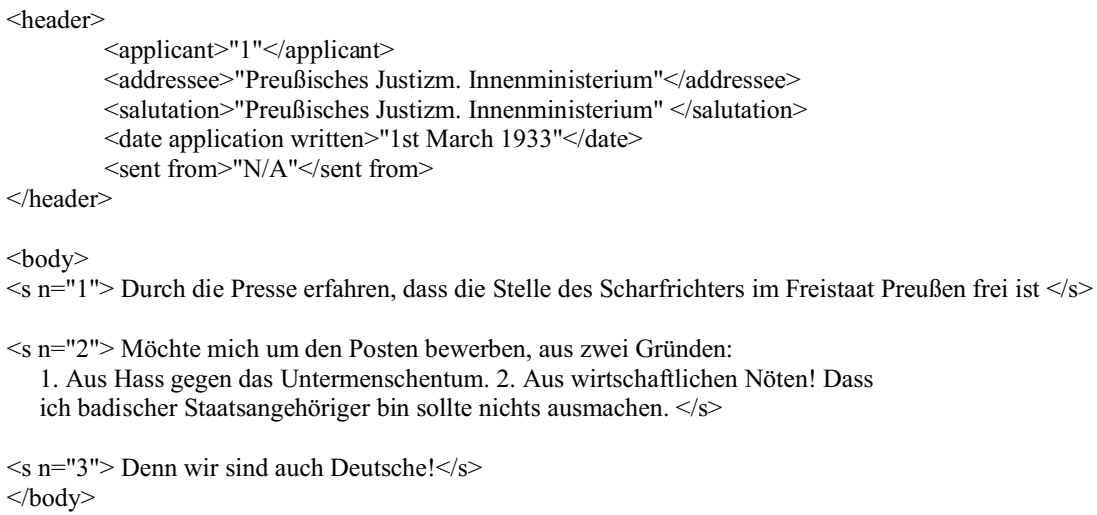

Fig. 1 Example of application letter written in 1933 (applicant 1)

record of natural language behaviour and phenomena. The authenticity of the letters is one of the aspects that allows us to transform the original letters into a specialized corpus and to proceed with an analysis using Antconc and Lancsbox.

We do so given that the collection of data, to the extent that we may argue for the authenticity of the letters, is not believed to have been systematically observed or elicited by a linguist. In addition, we acknowledge Sinclair's concern with "minimum disruption" [45: 25] to exist primarily within spoken corpora, meaning that it does not directly apply to our corpus in this manner. However, there is a 'disruption' that occurred in transferring the written words from the physical letters into the various digital formats for the purposes of building the corpus. For the corpus in our study this disruption in the authenticity of the data applies to our written corpus to the extent that "visual information about the font [of the letters], [their] color and size, the position of the text on the page, and the tactile properties of the paper are removed" [45: 24]. This information was not intentionally removed, and was lacking when the data was collected. We manually developed a 'clean-text' version of the corpus, without annotations, and simple transcriptions. Regarding the evaluation of data, we agree with Stefanowitsch, who argues that "in observational studies no disruption is ever minimal" [45: 25].

The collection of the application letters required careful attention to confidentiality as they hold sensitive identifying information. This information was retracted from the corpus as the privacy of the applicants is intended to remain intact. The 178 letters were subsequently transcribed manually in a Microsoft Word document and validated against the images of the original applications for accuracy. This resulted in one overarching transcription folder from which we proceeded to implement XML markup annotation. The decision to apply XML annotation to the letters was made to develop a more robust corpus including corresponding metadata. Each application resulted in two txt files, which are kept in separate locations so as to further manage privacy of data.

During the initial stages of building the corpus, we were able to identify nominal variables as defined by Stefanowitsch [45: 143]. This data, for instance, allowed us 
to analyze how many of our participants are married or single. In addition to nominal variables we also found cardinal variables. Cardinal variables are demographic variables such as age or income [45: 147]. Examples evident in our dataset include, for instance, the number of children applicants state they have. Most applicants mention their age, yet none of the applicants mention exact numbers when it comes to their income. An example file of applicant 1's annotated letter from the corpus is found in Fig. 1, which includes examples of the tags created:

Bitte (V: please, N: request) ranks as the $18^{\text {th }}$ most frequently used word throughout the CNSAL. Scharfrichter (executioner) ranks as the 15th most frequently used word in the corpus. This allows us to assert that the majority of individuals who submitted an application must at least have had a certain degree of conscious knowledge of the actions to be taken as part of the position they sought to obtain. At the very least, as presented by Andersen [2: 548], these findings represent "the choices made by language users and as surface manifestations of the underlying communicative competence of the speakers whose language the corpus represents". For instance, bitte ranks at 18th; the high frequency of this item appears indicative of a "pattern [...] of discourse" [2: 548]. In this study we present "different levels of analysis" [2: 549], integrating insights from discourse analysis, legal history, and stylistics. The assistance of corpus linguistics in this study was provided to allow for an empirical consideration of data. The following section will provide a qualitative description of stylistics choices made throughout a randomly selected sample of 100 application letters.

\section{Submissive Language Use in Letters of Application: the Stylistics Perspective}

Due to its roots in Russian formalism, stylistics has historically been concerned with the analysis of literary texts. In recent years, however, stylisticians are becoming more and more accepting of the idea that such techniques of analysis can also be applied to non-literary texts. As asserted by Jefferies and McIntyre, "we might try to define literature as distinct in some way from 'ordinary' language, the same kinds of stylistic phenomena turn up in all sorts of text" [25: 15]. Such textual features are certainly present in the letters of application of would-be Nazi executioners, and stylistic analysis is an effective means of exploring the ideology of obedience within them. A stylistic analysis is especially fitting for this research project, CDA having a family resemblance to stylistics as a sub-discipline, particularly in its positioning of text at the centre of its concerns.

100 letters have been randomly selected for analysis to represent the corpus as a whole. We have chosen to limit the number of letters because, as with most stylistic studies, the broader the scope, the less detail it is possible to include and the less comprehensive it is possible to be [25: 178]. Though there are some aspects of quantitative analysis, e.g. recording the number of salutations to Hitler or the number of uses of reverential titles, this section will mainly be concerned with stylistic analysis. Within a 100-letter sample, each letter was categorized according to the applicant's motivation for applying. The United States Holocaust 
Memorial Museum groups individuals' motivations into two broad categories: first, cultural (including ideology and antisemitism); and second, social-psychological (fear, opportunism, pressures to conform and the like) [50]. Wilhelm Reich opposes the idea that fascism spreads due to the actions of specific political leaders. Marxian understandings which place socio-economic factors at the heart of authoritarian movements are also rejected; Reich instead asserts that fascism is the natural expression of individuals whose innate biological instincts and needs have been smothered by a society that is inherently dictatorial and sexually repressive. He goes on to argue that if fascism is to be defeated, it must be studied through a psychoanalytical lens. He believes that this method alone can dismantle forms of organized mysticism (e.g. the authoritarian family ideology, the Church, etc.) and the fascist structures facilitated by them (see also [1:228]). Reich states:

Psychoanalysis should fulfil a scientific function which socio-economics cannot fulfil: the comprehension not of the historical soil of the ideology, but of its structure and dynamics. By including the discoveries of psychoanalysis, sociology reaches a higher level and becomes better able to comprehend reality because, finally, it includes the knowledge of human structure [35: 228].

Fromm took an approach for which we consider legal linguistics and CDA to be of high relevance. In his Survey on Workers and Employees of 1929/1931 he used interpretative surveys to help determine the frequency of different political social attitudes and draw conclusions about unconscious tendencies and drive structures of the respondents (Theory of Social Character) [16: 8]. Analyzing the answers, he and his team posed an important argument: Attitudes and prejudices were based on no more than the adoption of thought models represented by society in general or by a particular group, and were not solely based on inner thought processes developed in a vacuum. [16: 10]. Accordingly, answers of the individuals would not express their emotional attitude but the ideology of the group they accepted. In order to differentiate authentic answers from ideologically adapted phrases, it would not only be important to know the ideology and stereotypical ideas they are embedded in but to pay special attention to the small details of their utterances, formulations and choice of certain words, as well as on contradictions between their own assertions, about which the respondents themselves might not have been aware [16: 14].

With these parameters in mind, letters were sorted into the following three groups:

Group 1: Letters in which the applicant emphasizes his financial difficulties and desire for paid work (19 letters fall into this category)

Group 2: Letters in which the applicant emphasizes his wishes to further the Nazi cause in the role of executioner (23 letters fall into this category)

Group 3: Letters in which there are few details of the applicant's motivation to apply. These letters are usually little more than personal profiles or lists of work history (58 letters fall into this category) 
The majority of letters fall into group 3. This may be exemplified by reference to applicant 48 :

\section{(1) Original:}

'Herrn Reichsjustizminister Dr. N.N. Leipzig

Bewerbung!

Stelle den Antrag betreffs Einstellung als Scharfrichter für Rheinland und Westf.

Schrecke vor nichts zurück.

Bin verheiratet 1 Kind bin auch gesund und zielbewußt, festentschlossen.

Antragsteller N.N.

Lebenslauf

N.N geb. 2.4.89 zu Düsseldorf.

Bis 14 Jahre besuchte ich die Volksschule, dann lernte ich das FriseurHandwerk. Nach meiner Lehrzeit machte ich in meinem Beruf große Fortschritte 1910 errang ich die Bronzene Medaille 1911 die Silberne Medaille 1914 auf der Internationalen Gewerbe-Ausstellung die Goldene Medaille.

Vom 1. Febr. 1915-1918 als Frontsoldat Inh. E.K. II 29. Mai 1918 verwundet. Dienstgrad Gefreiter.

Aus dem Kriege zurückgekehrt ergriff ich wieder meinen Beruf.1925 errang ich das Ehrenkreuz zu Düsseldorf. Vom 1. Okt. 1929 - 1. April 1930 war ich als Gewerbe-Lehrer an der Städt.-Berufsschule zu Düsseldorf tätig. 1933 trat ich in die S.A. ein 1934 erhielt ich das S.A. Sportabzeichen. Und heute möchte ich mich umstellen und Scharfrichter werden dies war mein Wunsch schon vor 10 Jahren.

N.N.

Düsseldorf'

\section{English translation:}

'To the Minister of Justice Dr. N.N. Leipzig.

Application!

Making the request regarding employment as executioner for Rhineland and Westphalia. Do not shy away from anything.

Am married, 1 child, am also healthy and decisive, determined. Applicant N.N.

CV

N.N. born 2.4.89 in Düsseldorf.

I attended elementary school until the age of 14, then I learned the hairdressing trade. After my apprenticeship, I made great strides in my profession. In 1910, I won the bronze medal, 1911 the silver medal, and the gold medal at the International Trade Exhibition in 1914. 
From February 1, 1915-1918 as a front soldier with E.K. II wounded May 29, 1918. Rank: private. Returning from the war, I started my job again. In 1925, I won the Cross of Honour in Düsseldorf. From October 1, 1929April 1, 1930, I worked as a trade teacher at the municipal vocational school in Düsseldorf. In 1933, I joined the S.A. In 1934, I received the S.A. sports badge. And today I would like to change and become an executioner, this having been my wish 10 years ago.

N.N.

Düsseldorf'

Though the letter begins with a respectful salutation, the applicant does little else to convey his obedience to the Minister of Justice. On the contrary, he describes himself thus: 'Do not shy away from anything', in addition to using the words 'decisive' and 'determined', both in the semantic field of independence. In the CV section, the applicant lists his professional achievements, stating at the beginning that he 'made great strides in [his] profession' and that he won medals at the International Trade exhibit, and towards the end: 'I won the Cross of Honour' and 'I received the S.A. sports badge'. Though in isolation the latter two sentences could be interpreted as the applicant emphasizing his alliance to and recognition by the NS state, it is noteworthy that they come at the end of the list. He also places himself as the subject of these sentences, e.g. 'I won the Cross of Honour' rather than 'The Cross of Honour was awarded to me by The German Reich'.

He finishes the letter by stating that he wishes to leave his current profession and become an executioner, 'this having been my wish 10 years ago'. The applicant does not follow up on why he wants to become an executioner, only that it is his wish. There are sentences in the other letters that express the same meaning semantically, but are expressed in a far more subservient manner, e.g. applicant 2 (from group 2): 'I would like to offer to the 'Prussian State' my services as an 'executioner'. A salutation to Hitler is notably absent. The applicant has emphasized first and foremost his professional achievements and wishes, giving the overall impression to the reader that his own ambition is the driving force behind the application, rather than a desire to serve his Nazi superiors. Similar features denoting lack of obedience can be seen in many group 3 letters, i.e. the highlighting of one's personal and professional history rather than one's loyalty to the Nazi cause. While 40 out of 58 applicants do make salutations to Hitler at the close of their letters, only 7 applicants use markedly respectful or reverential language:

\section{Applicant 7:}

(2) Original:

'...möchte ich Ihnen, Hochzuverehrender Herr Ministerpräsident, die Bitte unterbreiten, mich bei der Beauftragung als Scharfrichter berücksichtigen zu wollen. [...] Ich habe mich nunmehr mit meiner Bitte an Sie gewendet Hochzuverehrender Herr Ministerpräsident' 


\section{English translation:}

'I would like to submit my request to you, Venerable Prime Minister, to consider me when assigning the position of executioner. [...] I have now contacted you with my request, venerable Prime Minister'

\section{Applicant 8:}

(3) Original:

'Da ich mich nun dem Vaterlande nützlich machen will, habe ich mich entschlossen das Scharfrichterhandwerk zu erlernen.'

\section{English translation:}

'Since I now want to make myself useful to the fatherland, I have decided to learn the trade of executioner.'

\section{Applicant 47:}

\section{(4) Original:}

'Ich bitte den Herrn Reichsminister des Innern, ganz gehorsamst mein Gesuch bei den zuständigen Stellen gütigst zu befürworten'

\section{English translation:}

'I ask the Minister of the Interior very obediently to kindly approve my request with the competent authorities'

\section{Applicant 49:}

(5) Original:

'Euer Hochwohlgeborener Herr Minister der Justiz bitte ich ganz besonders meine Bitte wohlwollend berücksichtigen zu wollen'

\section{English translation:}

'Your Highly Born Minister of Justice, please take my request benevolently into consideration'

Though these sentences certainly showcase the applicants' desire to emphasize their obedience and dedication, it is worth noting that all of these sentences, with the exception of applicant 80, appear close to or at the very end of the letters. The places at which these sentences appear within the letters are significant - their positions show that the applicants are not emphasizing their submission from the outset. Many applicants from group 1-those who applied mainly for financial reasonscan appear similarly unconcerned about showing that they are obedient, as seen with applicant 19, for example:

\section{(6) Original:}

'An den preußischen Justizminister

Ich der Unterzeichnete hätte eine Bitte an Sie, und zwar bitte ich den Herrn Minister mir eine Anstellung bei der preußischen Justiz zu verschaffen da ich Vater von 4 Kindern bin, und schon viele Jahre Arbeitslos bin, bin ich bald der Verzweiflung nahe, so bitte ich Sie noch einmal mit mir Rücksicht 
zu nehmen und mich ev. als Scharfrichter in Preußen mit zu beschäftigen. Bin 31 Jahre alt Schmied von Beruf. Ich würde mein Amt mit Größter Ruhe und Pünktlichkeit ausführen. Sollten Sie Interesse zeigen an meiner Bewerbung, so bitte ich Sie mir bald Bescheid zukommen zu lassen.

Ergebenst

N.N.'

\section{English translation:}

'To the Prussian Minister of Justice

I, the undersigned, would like to ask something of you, namely I ask the Minister to get me a job in the Prussian judiciary because I am the father of 4 children, and have been unemployed for many years, I will soon be in despair, so I ask you again to take me into consideration and possibly to give me a position as executioner in Prussia. I am 31 years old a blacksmith by profession. I would carry out my office with the greatest calm and punctuality. Should you show interest in my application, please let me know soon.

Most respectfully

N.N'

Unlike applicant 48, applicant 19 does state the reason for his application; it is not to serve the NSDAP, but to provide for his children. Though he uses a respectful salutation 'To the Prussian Minister of Justice' and politeness markers appear throughout, the applicant makes no explicit reference to his desire to submit to his superiors. He instead chooses to stress his 'calm and punctuality'.

Half of the letters in this group are of a similarly short length to applicant 19, and 8 of them make no salutation to Hitler at the end. Though (as will be discussed later in this section) some of the applicants in this section do make an effort to convey their obedience, it is clear that for many, their dedication, and by extension their obedience to the Nazi cause and its officials, is not their main motivation for applying. These letters unsurprisingly contrast with those in group 2, in which the applicants' key motivation for applying is to further the Nazi cause. Of these letters, 17 out of 23 applicants make salutations to Hitler at the end, and 16 use submissive and reverential language. An example of this can be seen in the opening and closing paragraphs of applicant 2 :

\section{(7) Original:}

'Sehr geschätzter Herr Minister, allergnädigster Herr!

Mit meinem heutigen ergebenen Gesuch gestatte ich mir ganz ergebenst, dem „Preuß. Staate“ meine Dienste als „Scharfrichter“ anzubieten und bitte untertänigst bei Vergebung einer vakanten Stelle um gefl. Berücksichtigung meines heutigen Schreibens.'

'Bitte prüfen und berücksichtigen Sie, hochverehrter Herr Minister mein heutiges ergebenes Gesuch und zeichne mit tiefer Verehrung mit einem „Sieg Heil“" auf unseren Reichskanzler und Führer Adolf Hitler. N.N.' 


\section{English translation:}

'Highly esteemed Minister, most gracious Lord!

With my respectful request today, I allow myself most respectfully to offer my services as an "executioner" to the "Prussian State" and to ask you most submissively to consider today's letter of mine if a vacant position is to be assigned.'

'Please review and consider, venerable Minister today's respectful request and I sign with deep veneration with a "Sieg Heil" for our Reich Chancellor and Leader Adolf Hitler.

N.N.'

This applicant makes a great effort to stress his subservience-politeness and respect markers appear frequently and variants of the word 'ergeben' appear three times. He also employs the use of reverential titles like 'highly esteemed' and 'most gracious', and refers to 'deep veneration' for Adolf Hitler in the body of the letter. These discursive devices appear often in group 2.

Birch states that "[1]anguage should be seen in terms of gradation or 'cline' which makes it possible to find elements of literariness in languages which would usually be defined as ordinary" [4: 111]. The letters analyzed in this section so far could be placed more toward the non-literary end of the cline, being fairly prosaic and bureaucratic from a stylistic perspective. However, many of the other letters contain elements of literariness, particularly with the use of rhetoric devices. This is evident in these extracts taken from applicant 38's letter:

\section{(8) Original:}

'Mit dem innersten Drang meines Herzens treibt es mich an Euer Hochwohlgeborenen diese Zeilen zu richten, denn ich glaube und hoffe bei Herrn Reichsminister an der richtigen Stelle zu sein und sein Herz im Vertrauen und Hoffnung ausschütten zu können.'

'Ich würde Ihnen mein Leben lang danken und verlangen Sie, was Sie wollen von mir im Interesse unseres Vaterlandes, denn ich kann zu jeder Stunde einem ehrlichen Tod frei ins Auge sehen.'

\section{English translation:}

'With the innermost urge of my heart I am driven to address you with these lines, Your High-Born, for I believe and hope to be in the right place with the Minister and to be able to pour his heart with confidence and hope.'

'I would be grateful to you all my life and ask whatever you want of me in the interest of our fatherland, for I can face an honest death at any hour.'

In his repeated emphasis of his own submissiveness, applicant 2 in a sense depersonalizes and dehumanizes himself - he frames himself as a passive participant who is willing to follow superior orders, whatever they may be. Contrastingly, applicant 38 stresses his personal and emotional investment in achieving the executioner's role by using emotive language (e.g. 'With the innermost urge of my heart', 'I can face an honest death at any hour') and figurative language ('...to be able to pour his heart with confidence and hope'). 
He also literally states that: 'I would be grateful to you all my life and ask whatever you want of me.' The applicant has clearly made great effort to convey his obedience.

Applicant 44 also tends toward the literary end of the cline:

(9) Original:

'Wohl selten wird eine derartige Bitte vorgetragen, und da werde ich auch die Gründe angeben, die mich hierzu bewegen: Horst Wessel und bestialische Ermordung von Krath und Roß am Gollenberge bei Köslin. 1. Mos. 4. 10 steht: Was hast du getan? Das Blut deines Bruders schreit zu mir von der Erde. 1. Mos. 9,6: Wer Menschenblut vergießt, des Blut soll wieder durch Menschen vergossen werden - und ich, sehr verehrter Herr Minister, möchte nun der sein der hierzu von Ihnen gesetzt wird.'

\section{English translation:}

'Such a request is surely made rarely, and I will also state the reasons that motivate me to do so: Horst Wessel and the bestial murder of Krath and Roß at Gollenberge near Köslin. Genesis 4.10 says: What have you done? Your brother's blood cries to me from the earth. 1. Genesis 9,6: Whoever sheds human blood, his blood should be shed again by people_-and I, venerable Minister, would now like to be the one you appoint for this.'

In Genesis 4.10, the "idea was that bloodshed, for which there was no avenger, cried to Jehovah for vengeance against the murderer" [20: 203]. In the quoting of this verse, the applicant declares his subservience by framing Nazi authority as God, and himself as God's servant. The God/servant dynamic can also be seen in the following group 1 letters, as visible in applicant 82:

\section{(10) Original:}

'Bittere Armut meiner Eltern (Tagelöhner) und mein Los als Hilfsarbeiter formten seinerzeit meinen Plan. Ich habe mich nun innerhalb meiner langen Arbeitslosigkeit (1920_fast 1938) unter Mühen und Entbehrungen als Autodidakt zum Externen Abiturienten emporgearbeitet. Lehrer oder Kurse hätte ich mir nicht leisten können.'

'Bitte Exzellenz, helfen Sie mir zu meinem Ziele: der Menschheit in meiner Weise dienen zu dürfen.'

\section{English translation:}

'My parents' bitter poverty (day labourers) and my lot as a manual worker formed my plan at the time. I have now worked my way up through labour and deprivation as an autodidact to become an external high-school graduate during my long unemployment (1920-almost 1938). I could not have afforded teachers or courses.'

'Please Excellency, help me achieve my goal: to serve humanity in my way.'

Though there is no explicit reference made to God or religion, both applicants frame the Nazi officials they are writing to as saviours. Applicant 82 calls upon 
their 'kindness' and vows to 'serve', and applicant 93 pleads for the role in order to 'save' his children and end his 'suffering'. The desperation in these letters is tangible_-both applicants stress their dire situations, their 'bitter poverty' and 'sleepless nights', the 'worry, misery and grief'.

Catt explores the link between desperation and obedience in a religious context. He states that "God doesn't need [...] gifts, talents or titles. What He wants is absolute obedience" [10: 69]. Catt references the countless religious figures who had to be brought to a point of desperation in order to truly demonstrate their faith and obedience. A parallel can be drawn between such figures and applicants 82 and 93. It appears their obedience is first and foremost a result of their economic desperation, rather than devotion to the Nazi cause - but, as should be emphasized, it is obedience with a totalitarian dictatorship nonetheless.

Jefferies and McIntyre assert that "some of the earliest discussions of stylistics emphasized that the choices available to writers [...] were evidence that there was something we could call 'style' which was separate and separable from the normal concerns of linguistics" [25: 26]. Although the passages 'Please Excellency, help me achieve my goal: to serve humanity in my way' and 'today I would like to change and become an executioner' can be considered semantically similar, the stylistic choices made by each applicant convey their individual dispositions regarding obedience.

In all three categories of letter to varying degrees, applicants employ the use of reverential titles, Nazi salutations, emotive language, politeness markers and words in the semantic field of obedience to show their obedience to the Nazi officials that they are addressing. However, this does not necessarily denote obedience in the writers themselves.

In his 2015 essay on the role of obedience pressures during the Holocaust, Fenigstein makes reference to the 1963 Milgram Experiment [15: 113], which is frequently cited to support the idea that obedience was a large contributing factor to the carrying out of Nazi atrocities. However, Fenigstein observes that

[a] critical element of the Milgram research was that obedience pressures were necessary to compel destructive actions in the face of moral resistance to those actions. [...] The potency of obedience can only be effectively demonstrated when it is opposed by a powerful force, such as the moral imperative against harming an innocent other [15: 113].

This view reframes the emphasis that applicants put upon their obedience and loyalty to their Nazi superiors, as the letters were being written long before they would be called to carry out destructive actions. Importantly, there is no pressure for them to obey at the point of writing. This observation supports Fenigstein's idea that

it makes little sense to attribute the behaviour of the perpetrators to powerful obedience pressures that supposedly overwhelmed their moral sensibilities; far more compelling is the conclusion that the perpetrators willingly followed orders because they believed that the order to kill [...] was right and just [15: 118]. 
These pre-existing beliefs can be observed in many of the application letters, such as the letters by applicants 52, 56 and 57:

\section{(11) Original:}

'Jene Menschen restlos zu vernichten, die ihre Daseinsberechtigung in unserem Vaterlande verloren haben, das ist mein Ziel das ich erstrebe u. erreichen will. Es ist dies mein sehnlichster Wunsch u. ich hege die zuversichtl. Hoffnung, weitgehendste Unterstützung bei Ihnen zu finden.'

\section{English translation:}

'To destroy completely those people who have lost their right to exist in our fatherland, that is my goal that I strive for and want to achieve. This is my dearest wish and I cherish the confident hope to find the most extensive support from you.'

\section{(12) Original:}

'Mit dem Gedanken, alle Verbrecher und Volksschädlinge, wodurch das deutsche Volk und das Leben desselben gefährdet ist, restlos auszumerzen, bitte ich Sie höflichst meinem Gesuch Gehör zu schenken.'

\section{English translation:}

'With the thought to eradicate completely all criminal and vermin, through whom the German people and the life thereof are endangered, I ask you most politely to give an ear to my application.'

\section{(13) Original:}

'Nicht Sensationslust ist es, was mich dazu veranlaßt diesen Beruf einzuschlagen, sondern meine Gefühle sind es, solche Kreaturen vernichten zu helfen, die in verbrecherischer Absicht das Leben und Eigentum friedlicher Menschen oder den Frieden des Landes gefährden.'

\section{English translation:}

'It is not sensationalism that causes me to pursue this profession, rather it is my feelings to help destroy creatures that, with criminal intent, endanger the life and property of peaceful people or the peace of the country.'

Therefore, while many of the applicants undoubtedly make an effort to emphasize their obedience and subservience in their letters, these features cannot necessarily be used to support the argument that obedience pressures were the driving force behind the atrocities carried out within the NS criminal justice system. In the following section, the quantitative and qualitative linguistic analysis of the lemma bitten, as used by applicants in the corpus, will be presented. 


\section{Linguistic Analysis}

\subsection{Requesting and Pleading in Executioner Applications: the Case of Bitte}

Ringel expresses the symbiotic relationship between rulers and servants, stating that while servants long for the receiving of commands, rulers are in need of individuals that are ready to humbly obey, and in doing so, allow rulers to abuse them for their own increasingly selfish goals [42: 214]. In the sociopolitical and historical context of the NS regime, Hitler's speech at the Nuremberg Rally of 1936 clearly captures this interdependence:

Daß Ihr gerade mich gefunden habt unter soviel Millionen Menschen, daß ist Euer Glück, und daß ich Euch gefunden habe, ist mein Glück [42: 214].

That you found just me amongst so many millions of people, that is your luck, and that I found you, that is my luck [authors' translation].

Importantly, the authoritarian state cannot function without the uttering of commands and their being carried out [42], and yet there is another set of speech acts that merits further contemplation, i.e. the role and function of requests to equals or to state authority. The symmetry or asymmetry pragmatically encoded in requests can be seen in the following three examples:

(14) Could you please pass me the salt?

(15) I am asking the court for a lenient sentence.

(16) I am asking from the bottom of my heart, my leader, give me the opportunity to eradicate criminality.

In his typology of requests, Hindelang distinguishes between symmetrical and asymmetrical requests [24: 63]. While symmetrical requests only refer to those speech acts that could be performed by both agents in a different context, asymmetrical request can only be made by the speaker who is entitled as a result of their social status and authority. In short, therefore, [1] is a clear example of a symmetrical request, since irrespective of the social status, all speakers at the table may wish to ask for the salt. In contrast, (2) and (3) are typical examples of asymmetrical requests since an exchange of roles is possible neither when in court nor in communication with a dictator. The requests under investigation in our study largely belong to the group of asymmetrical requests in the context of the criminal justice system, that is, inter alia, requests made to officials of the NS state to be granted a position as executioner. Though requests in German can also be expressed using other performatives than bitte such as 'ersuchen' or 'ansuchen', our analysis focuses on the use of bitte in the letters of application.

This performative has not only been chosen in order to adhere to the space limitations, but also since it is the most frequently occurring type of request in the corpus. We hypothesize that this performative is multifunctional, i.e. it is not only intended to express a request for employment, but may also be used to emphasize the applicant's submission and obedience to the totalitarian state. Following this hypothesis, we assume that the way requests are made in the communication with the NS 
Table 2 Types of requests made to NS authorities

\begin{tabular}{llrr}
\hline Rank & Type of request & \multicolumn{2}{c}{ Frequency } \\
\cline { 3 - 4 } & & Abs. & $\%$ \\
\hline 1 & Position & 34 & 28.3 \\
2 & Information about position & 26 & 21.7 \\
3 & Acceptance of application & 21 & 17.5 \\
4 & Reply to application & 18 & 15.0 \\
5 & Review of application & 10 & 8.3 \\
6 & Taking note of interest & 6 & 5.0 \\
7 & Neutral response & 5 & 4.2 \\
Total & & 120 & 100 \\
\hline
\end{tabular}

criminal justice system can be illuminating for the analysis of totalitarian ideologies as evident in systematic linguistic practice. We aim to illustrate this with reference to examples taken from the application letters. In the following section, the empirical study is presented with a view to showing the most frequently occurring uses of bitte in context.

\subsection{Quantitative Analysis}

In this section, the analysis of the frequency distributions of requests will be presented. The lemmas bitten ('ask for something') and Bitte ('request') occur in $81.22 \%$ of application letters. While only $24.86 \%$ of application letters contain the lemma Bitte, $79.01 \%$ of the texts feature the lemma bitten in its various grammatical forms. Therefore, the distribution of the lemma bitten was further analyzed regarding its use across the application letters. Notably $59.67 \%$ of all letters contain the lemma bitten in the first-person singular, i.e. the performative ich bitte. In contrast, only $9.39 \%$ of letters feature the lemma bitten in the third-person singular, e.g. Unterzeichneter bittet. The infinitive bitten occurs in $9.94 \%$ of letters and is typically used along with a modal verb, such as möchte bitten. This leads to the conclusion that when compared to the other forms, the most frequently occurring form of the lemma bitten is the first-person singular. The quantitative analysis shows that the use of the first-person singular form seems to fulfil seven main types of request that are shown in Table 2 below.

It is evident from the distribution of requests expressed in the first-person singular forms ich bitte and bitte ich that the most frequently expressed speech act is that of requesting employment as an executioner ( 28\%), e.g. "Ich bitte darum höflichst mir so einen Posten zu übertragen" ('I ask most politely for you to assign such a post to me'). Other types of request reflect the applicant's wish to obtain more information about the position $(\sim 22 \%)$, to accept the application $(\sim 18 \%)$, to respond to the application (15\%), for the authority to review the application ( 8\%), to take note of the applicant's interest (5\%), and to reply to the application letter in a neutral manner ( 4\%). This seems to corroborate Bhatia's argument that "each move also serves a typical communicative intention which is always subservient to the overall 
Table 3 List of abbreviations as used in this paper

\begin{tabular}{ll}
\hline Abs. & Absolute \\
CDA & Critical discourse analysis \\
CNSAL & Corpus of national socialist application letters \\
DHA & Discourse-historical approach \\
DIMEAN & Multi-layered discourse analysis \\
N.N. & First name/last name \\
NS & National Socialism/National Socialist \\
NSDAP & National Socialist German Workers' Party \\
RStGB & Criminal Code/Reichsstrafgesetzbuch \\
SA & Sturmabteilung \\
XML & Extensible Markup Language \\
\hline
\end{tabular}

communicative purpose of the genre" [3: 30]. However, in order to gain more contextually reliable insights into the use of requests in the letters under investigation, it is essential to conduct a qualitative analysis. This particularly holds true for requests that are not easily categorized or constitute extreme examples of the applicant's submission and willingness to obey. The results of and conclusions drawn from the qualitative analysis are presented in the remainder of this section.

\subsection{Qualitative Analysis}

As previously discussed, the majority of letters $(79.01 \%)$ contain addressee-oriented requests, with $59.67 \%$ being expressed in the first-person singular form. In the qualitative analysis, focus will now be placed on the immediate co-text as well as the legal-historical context of the letters. To achieve a systematic analysis and presentation of findings, the types of requests will first be introduced and defined, the most typical examples stated and discussed, and conclusions drawn. Importantly, it should be emphasized that the qualitative analysis does not seek to achieve representativeness, but is intended to detect, isolate, and describe patterns of linguistic practice that would have gone unnoticed in the quantitative analysis (Table 3).

\subsubsection{Requests to be Granted the Position}

Approximately $28 \%$ of requests aim to express the applicant's wish to be employed as an executioner by the justice system. Nevertheless, the qualitative analysis reveals that these requests construct a more fine-grained set of motives, which can be seen in (17) and (18) below:

(17) Original: 'Ich bitte daher um Einstellung als Scharfrichter.'

English translation: 'I therefore ask for employment as executioner.'

(18) Original: 'Ich bitte darum höflichst mir so einen Posten zu übertragen.'

English translation: 'I ask you most politely to assign such a post to me.' 
These two examples show that the main function of the request is to achieve employment. However, not all requests for a position addressed to the authority are restricted to this communicative aim only, as requests for the position are also combined with other aims, as shown below:

(19) Original: 'Um mich in dem Beruf auszubilden, bitte ich mich zu Hinrichtungen, wenn angängig in Madgeburg, zuzulassen'

English translation: 'In order to be trained in the profession, I ask you to admit me to executions in Magdeburg should they be carried out.'

(20) Original: 'Sollte ich augenblicklich nicht als Scharfrichter Stellung erhalten können, so bitte ich als Helfer angestellt zu werden.'

English translation: 'Should I not be eligible for the position of executioner at this time, I ask to be employed as assistant.'

As visible in the examples, some applicants construct their aim to obtain the position as being intertwined with other endeavours, such as [19] to receive training in the profession, and [20] to be employed as an assistant to the current executioner. It may be argued that this construction of divergent personal aims as to why the applicant might be particularly suitable for the position is a reflection of the applicants' willingness to engage in judicially sanctioned homicide. This is not to argue that some applicants only applied to the justice system or another administrative body to serve the government in power and/or kill other individuals, since some applicants explicitly state financial distress as the primary motive underlying their application. However, in some cases the letters clearly express the applicants' desire to be employed specifically in the context of judicial homicide, be it in the full position of executioner or as an assistant. This leads to the conclusion that requests for the position of executioner present themselves as being multifunctional and hybrid speech acts, which is reflected in the social relationship between the applicant and the administrative body.

\subsubsection{Requests To receive Information About the Position of Executioner}

The second most frequently occurring types of requests pertain to the group of requests for information about the position of executioner $(\sim 21 \%)$, as shown in the examples (21) and (22) below:

(21) Original: 'Ich bitte hiermit um Auskunft, wer Scharfrichter werden kann und unter welchen Bedingungen.'

English translation: 'I hereby ask for information about who can become an executioner and under which conditions.'

(22) Original: 'Ich bitte den Volksgerichtshof um Auskunft, ob die Möglichkeit für mich besteht, die Stelle eines Scharfrichters bei denselben zu erreichen, da mein Ahne auch Scharfrichter am österr. Hof war.' 
English translation: 'I ask the People's Court for information as to whether there is a possibility for me to achieve the position of executioner at that place, since my ancestor was also an executioner at the Austrian [royal] court.'

These examples are more coherent in their communicative intention, i.e. to inquire about the conditions and requirements of employment. Inquiries for more information may be grouped in two types, that is, individuals making a general request for information about the position and those who relate their request to their personal situation, clearly indicating that they themselves would be willing to carry out the function of executioner. The high frequency of requests of this type shows that while applicants seem to have a clear picture of the position for which they are applying, they mostly lack information about the requirements, duties, responsibilities, and skills.

\subsubsection{Requests for the Application to be Accepted}

Approximately $17 \%$ of first-person requests express the appeal to the administrative body to consider their application. This subtype of the speech act is usually performed as part of a post-request, i.e. a request made to either expand or emphasize again the perceived importance of their application. Examples (23) and (24) show two typical post-requests for acceptance of the applicant's request to serve as executioner:

(23) Original: 'Ich bitte höflichst mein Gesuch wohlwollend zu berücksichtigen.'

English translation: 'I ask you most politely to favourably consider my request.'

(24) Original: 'Ich bitte nochmals um Berücksichtigung meines Gesuches u. verbleibe mit Heil Hitler'

English translation: 'I ask you again for consideration of my application and remain with Heil Hitler'

Applicants' request for acceptance are in most cases formulated as a rhetorical strategy reinforcing their wish to occupy the position of executioner. Some applicants do not at all make use of this strategy, or only do so in the final lines of their letter. Applicant 56, for instance, uses it at the beginning, stressing his conviction to do away with who he refers to as criminals and vermin (Volksschädlinge):

(25) Original: 'Mit dem Gedanken, alle Verbrecher und Volksschädlinge, wodurch das deutsche Volk und das Leben desselben gefährdet ist, restlos auszumerzen, bitte ich Sie höflichst meinem Gesuch Gehör zu schenken.'

English translation: 'With the thought to eradicate completely all criminal and vermin, through whom the German people and the life thereof are endangered, I ask you most politely to give an ear to my application.'

In conclusion, while the majority of these types of request function as complimentary closings, some applicants use them to express their interest in the position 
or to stress their ideological consolidation, especially with regard to the ideology of eradication of individuals constructed as worthless.

\subsubsection{Requests to Receive a Reply}

About $15 \%$ of requests contain the call for action to reply to the applicant's letter. In nearly all letters containing this type of request it is found in the final lines of the application, verbalizing the applicant's hope to receive a response from the authority addressed in their letter, as seen in examples (26) and (27):

(26) Original: 'Ich bitte allerergebenst um diesbezügliche Rückäußerung.'

English translation: 'I ask you most respectfully for a response in this matter.'

(27) Original: 'Ich bitte die hohe Behörde um baldige Nachricht.'

English translation: 'I ask the high authority for an early reply.'

These requests clearly show how submission is linguistically realized, i.e. the social distance between the applicant and the addressee is made explicit by expressing writer-oriented obedience ("allerergebenst", "ergebenst") and by using a metaphorical description of space to stress the importance of the administrative body in question (hohe Behörde, 'high authority'). While this cannot be discussed here at length, the difference between submission and politeness merits further inquiry so as to gain deeper insights into the mechanism operative in totalitarian discourse.

\subsubsection{Requests for the Application to be Reviewed}

Approximately $8 \%$ of first-person requests contain a call for action directed at the authority to review the application. In most cases in the ending lines of the application letters, these types of request tend to express consignment of the outcome of the application to the deciding authority, as can be seen in examples (28) and (29):

(28) Original: 'Da ich Interesse an dem Beruf eines Scharfrichters habe, möchte ich mich um diesen Posten beim Reichsjustizministerium bewerben und bitte höflichst, mein Gesuch einer Prüfung zu unterziehen.'

English translation: 'Since I take interest in the profession of executioner, I would like to apply for this post at the ministry of justice and ask you most politely to review my request.'

(29) Original: 'Ich bitte Herrn Minister mein Gesuch zu prüfen und mich bei Bedarf gütigst zu berücksichtigen.'

English translation: 'I ask the Minister to review my request and to consider me if required.'

It appears that applicants are aware about the social distance operative in the communicative situation, i.e. whether their application will be successful remains entirely dependent on the recipient's interpretation of their application. The requests 
here largely revolve around an objectification of the reviewing process, i.e. the applicant's expectation that they are a suitable candidate for the position which might also be acknowledged by the reviewing authority. These types of requests seem to be related to the much rarer one expressing the applicant's plea not to reject the application immediately, as shown in the example below:

(30) Original: 'Ich bitte deshalb höflichst, nicht sogleich eine Absage zu erteilen in Hinsicht auf meinen Beruf.'

English translation: 'I therefore ask most politely not to immediately issue a rejection with regard to my profession.'

This seems to support our hypothesis that the applicants are largely aware of the power relations between the totalitarian state and themselves, that whether or not their application is accepted, they are willing and prepared to be and remain servants rather than employees. Importantly, the position of executioners had for long time been stigmatized as an untouchable profession, since it was associated with spilled blood and death which, in this context, might have encouraged individuals from less prestigious professions to apply for this even less respected activity.

\subsubsection{Requests for a Note of Applicant's Interest to be Taken}

About $5 \%$ of requests contain the applicant's wish for the authority to make a note of the interest the applicant takes in the job. In all letters that contain this rhetorical strategy, applicants seem to hope for vacancies in the future that will eventually allow them to obtain the position, as seen in examples (31) and (32):

(31) Original: 'Falls zu derzeit selbige noch besetzt sind, bitte ich höflichst um gütigen Vermerk.'

English translation: 'If it [=the position] is currently occupied, I ask you most politely to make a valid note.'

(32) Original: 'Ich bitte daher den Herrn Reichsminister mich für dieses Amt vorzumerken.'

English translation: 'I therefore ask the Minister to note me down for the position.'

As visible in the examples, the rhetorical strategy of asking the authority to make a note of the applicant's interest seemingly serves to mitigate a potentially adverse outcome of the application process. The applicant at least accepts the possibility that their application might be unsuccessful at the point of writing due to all positions in the state being occupied. It may be argued that this shows the seriousness and determination some applicants feel about their professional future, since, it seems, some applicants are not content with finding any kind of work, but instead express their explicit wish to work as executioners specifically. This at least suggests a high degree of voluntarism in some applicants that constitutes a defining element of their obedience. 


\subsubsection{Requests for a Neutral Response to be Issued}

The last main type of request found in the corpus essentially pertains to face theory (sensu [17]), since some applicants are seemingly concerned about the way they are perceived and appreciated by others. However, only $4 \%$ of requests contain the applicant's wish to conceal the application process from other individuals, which is visible in the following examples:

(33) Original: 'Ich bitte um Ihre gefl. Äusserung, bitte aber gleichzeitig, das Schreiben neutral zu gestalten.'

English translation: 'I ask for your deliberate response, but at the same time I ask you to style the letter in a neutral manner.'

(34) Original: 'Bei Beantwortung dieses Schreibens bitte ich, den Beruf nicht zu benennen, außerdem, an mich persönlich zu vermerken.'

English translation: 'When replying to this letter I ask you not to state the profession and to address it to me personally.'

As previously mentioned, the position of executioner was and is commonly associated with a powerful social stigma due to which the work and the person involved in it are close to shunned. In his interview with a death row warden in Oregon, United States, Pearl received the following description of the position: "What is commonly called 'executioner' is not a career [...]. Think of them as soldiers [...] in the war against crime [...] sent into a tiny room to kill somebody" [34]. Notably, when revisiting the social structure of NS Germany, soldiers presumably were in much higher regard in the general population during the time of the NS dictatorship than were executioners. Even though the number of applicants stating the wish for their application to remain anonymous is relatively small, it is reasonable to assume that the position of executioner was still associated with a strong social stigma not operative with soldiery. Therefore, in exchange for executioners' obedient services, the NS state did not only provide financial compensation but also silence and anonymity.

\section{Results}

The linguistic analysis revealed seven main insights into the use of first-person requests in the application letters. While the tendencies encountered in the quantitative analysis could largely be confirmed, the close reading and analysis of the texts shows that the requests made in the application letters are more diverse and varied than previously expected.

Requests for the position of executioner may in some cases be associated with a high level of multifunctionality and hybridity in terms of the speech acts assignable. This in part also holds true for requests to obtain more information about the position, where applicants have a general idea of the work, but lack 
information regarding the duties, responsibilities, and skills required of them. Requests for the application to be accepted seem to have been expressed with a view to reinforcing the applicant's wish to obtain the position, and/or to show and emphasize their ideological consolidation. Similarly, requests to review the application clearly indicate how applicants linguistically realize submission, which is made explicit in obedient language use and the use of metaphorical description of space, acknowledging the authority of the addressee. (e.g. 'high authority', 'hohe Behörde').

It also appears that some applicants are willing and prepared to function as servants rather than employees in fulfilling a dutiful task to the state. Requests to make a note of the applicant's interest are often used to mitigate a potentially negative decision in the application process, but also show how serious and determined some of the applicants were about their choice of work. The analysis also shows that while requests to issue a neutral response remain a relatively small group, the fact that some of the applicants ask for their letter to be treated confidentially supports our assumption that the position of executioner still carried a powerful social stigma, even during the NS dictatorship. The following section will provide a discussion of insights gained in the course of the study presented.

\section{Discussion}

The interdisciplinary approach taken towards the analysis and interpretation of the data in the course of this study raises numerous questions that need to be addressed. Due to space limitations, we will only be able to touch upon the most pressing issues at hand.

As Thieberger et al. note,

[d] ata accessibility is integral to developing the highest research standards in linguistics and other disciplines. Paired with advances in digital media, accessible corpora of annotated language data not only allow for verification of current analyses; they will, in time, provide answers to as yet unknown research questions, as well as providing a cultural record of value to the broader community [47: 2].

Corpus linguistics is not tied to applied legal linguistics, or indeed to any other field of linguistic inquiry. The process of overcoming "academic tribalism" [31: 45] is particularly fruitful in problem-solving research contexts where interdisciplinarity is not a bonus, but clearly a basic requirement. Making data accessible to researchers from what is often framed as 'other' disciplines should thus be a primary consideration, not only to ensure the replicability of findings, but also to enable researchers to ask and answer questions of which humanity is currently not immediately aware. The degree of data accessibility is also linked to the question as to how translations of corpus data should be conducted, which particularly holds true for data that displays high complexity due to the historical legal context in which it is was created. This being said, it was our aim to provide accurate translations of the application letters. We do, however, 
recommend a consultation of the original German sources to obtain a full understanding of the literal meaning.

The analysis of the transtextual domains of obedience is a challenging one. This project set out to explore how a shared discourse of obedience is constructed by the applicants and how this discourse is operative in the application letters. Having considered Widdowson's criticism that in CDA the line between political commitment and social/linguistic theory is increasingly blurred [52], we stress that while an extensive and thorough empirical approach has been taken, we do not claim that obedience itself is explicitly evident in all letters of application. However, what is evident in these texts is the applicants' readiness to willingly submit themselves to the NS authority. In this sense, we propose that obedience constitutes an ideology, or more precisely, an ideological constituent that forms the basis of authoritarian systems, be they politically, economically, socio-culturally or religiously motivated.

In the context of NS, the ideological bias in and interdisciplinary analysis of application letters opens a window into applicants' biographies, personal life situations and circumstances, and, perhaps most importantly, their expectations towards the job for which they are applying. We agree that "context is not experienced in isolation", that "[i]t too is an analytical construct" [53: 75]. The task at hand was, and will continue to be for those using the dataset, to "adduce contextual correlates as relevant to the projection of pragmatic meaning" [53: 75-76]. In the case of the application letters, context must necessarily include all available semiotic practices within specific fields of the NS criminal justice system, in legal scholarship and beyond for social critiques to follow a critical analysis of historical language use.

The analysis suggests that agents shape discourse. It is agents who act with language, it is agents who play the language games (sensu [54: xxxix]) of applying, of pleading, of confessing one's obedience and submission to authority. The theoretical considerations underlying Spitzmüller and Warnke's multi-layered model of analysis (DIMEAN) serve as a helpful basis to approach critically both the historical language user and the historical language used [44]. This should be done, as we argue, with the aim to reveal systematic tendencies in linguistic practice which can then be used to identify, isolate, analyze and interpret the schemata, frames, and scripts operative in historical discourses and co-discourses. Future research perspectives may thus place more focus on the agent layer [44]. To make explicit to researchers outside of the various schools of discourse analysis, it is necessary to demonstrate how exactly discursive practice shapes rules and roles in interaction and how discursive situations can be reshaped. Due to space limitations and the strict allocation of resources involved in this project, it was, for instance, not possible to analyze or discuss the responses of the NS authorities at all. It is our hope that a systematic interdisciplinary analysis of NS language use in legal institutions, such as the Volksgerichtshof, the Reichsgericht, or the Kammergericht will be conducted in the future. 


\section{Conclusion}

This article has set out to explore whether obedience and submission are empirically recoverable constructs in applicants' letters of application. The historical legal analysis shows that the position of executioner was associated with an ambivalent reputation, which also holds true for the time of NS. Not only was their personal data kept strictly anonymous by the authorities, with reference made to them only as 'judicial clerks' or 'judicial assistants', the relationship between the individual, their position and the NSDAP was a seemingly opaque one. Indeed, it may be argued that NS authorities were interested in keeping it that way, which is evident in the Guidelines for Executioners prohibiting NS symbolism, such as the Hitler salute in the course of executions. Institutional avoidance of those carrying out capital punishment was a reflection of traditional social ostracism of the executioner profession. This is suggested by some applicants' request for a response to their application in a neutral manner so that others would not know about it.

Secondly, the stylistics analysis of application letters shows that applicants do indeed use emotive language and allegory, lexis in the semantic field of obedience, giving reverential titles to individuals of authority and with frequent respect and politeness markers. Application letters could be grouped in three categories, that is, the applicants' emphasis of financial difficulties and desire for paid work (I), the wish to further the Nazi cause in the role of executioner (II) and those with only few details of the applicant's motivation to apply, including little more than personal profiles or lists of work history (III).

Thirdly, bitte was found to be the 18th most used word in the CNSLA, as a speech act likely to be used to express submission. This further warrants the observation that the use of bitte is an indication for systematic linguistic practice and thus, to a degree, representative of a construct within the discourse of obedience. While the syntax of requests made to the authorities may vary, the implication of submission, as an act that implies obedience to the state, remains. The linguistic analysis of firstperson requests including the lemma bitten across the CNSAL reveals that the act of requesting shows a more varied picture than initially anticipated. Requests for the position of executioner show a considerable level of pragmatic multifunctionality and hybridity regarding the speech acts potentially intended by applicants. Other types of requests encountered in the analysis include requests for more information about the position, requests for the application to be reviewed, requests for a note to be made of the applicant's interest and requests for a neutral response to be issued.

It is concluded that a systematic analysis of NS language use of legal institutions should be conducted in the future to allow for a synthesis, meta-analysis, and integration of data and findings across disciplines.

Acknowledgements This article is based on the project "'Aus Hass gegen das Untermenschentum': Exploring the Discursive Construction of Obedience in Executioners' Applications in the Third Reich", and was presented at the 21st Roundtable for the Semiotics of Law and The 15th Conference on Legal Translation and Interpreting and Comparative Legilinguistics (2020). The project was supported by the Austrian Association for Legal Linguistics (AALL), Vienna. We express our gratitude to Luke Green, Klaus Hillenbrand, Richard Bonomo, Stefan Th. Gries, Gregory R. Johnston, and the peer reviewers for their helpful feedback to the final version of this article. 
Funding Open Access funding provided by University of Vienna.

\section{Compliance with Ethical Standards}

Conflict of interest The authors declare that they have no other conflicts of interest.

Open Access This article is licensed under a Creative Commons Attribution 4.0 International License, which permits use, sharing, adaptation, distribution and reproduction in any medium or format, as long as you give appropriate credit to the original author(s) and the source, provide a link to the Creative Commons licence, and indicate if changes were made. The images or other third party material in this article are included in the article's Creative Commons licence, unless indicated otherwise in a credit line to the material. If material is not included in the article's Creative Commons licence and your intended use is not permitted by statutory regulation or exceeds the permitted use, you will need to obtain permission directly from the copyright holder. To view a copy of this licence, visit http://creativecommons.org/licen ses/by/4.0/.

\section{References}

1. Adorno, Theodor W., E. Frenkel-Brunswik, D.J. Levinson, and R.N. Sanford. 1950. The authoritarian personality. New York: Harper and Row.

2. Andersen, Gisle. 2012. How to use corpus linguistics in sociolinguistics. In The Routledge handbook of corpus linguistics, ed. Anne O’Keeffe, and Michael McCarthy, 547-563. London: Routledge.

3. Bhatia, Vijay K. 1993. Analysing genre: Language use in professional settings. London: Longman.

4. Birch, David. 1989. Language, literature, and critical practice: Ways of analysing text. London: Routledge.

5. Brockhaus, F. A., ed. 1941. Der Neue Brockhaus: Allbuch in vier Bänden und einem Atlas. Zweiter Band $F-K$. Leipzig: Brockhaus Leipzig.

6. Bundesarchiv Berlin. 1938-1939. Zuständigkeit Bd. 4. BArch R3001/ 21232. 66, 86, 222.

7. Bundesarchiv Berlin. 1934-1939. Allgemeines und Einzelfälle Bd. 1. BArch R3001/21323. 66, 86.

8. Bundesarchiv Berlin. 1939-1944. Allgemeines und Einzelfälle Bd. 2. BArch R3001/21324. 117.

9. Bundesarchiv Berlin. 1934-1944. Vollzug der Todesstrafe Bd. 1. BArch R3001/21314. 119, 179.

10. Catt, Michael. 2009. The power of desperation: Breakthroughs in our brokenness. Nashville: $\mathrm{B} \& \mathrm{H}$ Publishing Group.

11. Dachs, Johann. 1996. Tod durch das Fallbeil: Der deutsche Scharfrichter Johann Reichhart (18931972), 2nd ed. Regensburg: MZ-Buchverlag.

12. Evans, Richard. 1996. Rituals of retribution: Capital punishment in Germany 1600-1987. Oxford: Oxford University Press.

13. Fairclough, Norman. 1995. Critical discourse analysis. London: Longman.

14. Fairclough, Norman. 1996. A reply to Henry Widdowson's 'Discourse analysis: a critical view'. Language and Literature 5 (1): 49-56.

15. Fenigstein, Alan. 2015. Milgram's shock experiments and the Nazi perpetrators: a contrarian perspective on the role of obedience pressures during the Holocaust. Theory and Psychology 25 (5): 581-598.

16. Fromm, Erich. 2019. Arbeiter und Angestellte am Vorabend des Dritten Reiches. Gießen: Psychosozial Verlag.

17. Geheimes Preuß. Staatsarchiv. I. HA Rep. 84a. 1934. Justizministerium.

18. Girnth, Heiko. 1996. Texte im politischen Diskurs. Ein Vorschlag zur diskursorientierten Beschreibung von Textsorten. Muttersprache 1: 66-80.

19. Glenzdorf, Johann, and Fritz Treichel. 1979. Henker, Schinder und arme Sünder. Bad Münster am Deister: W. Rost.

20. Gordon, Alexander R. 2019. The early traditions of Genesis. Buffalo WY: Creative Media Partners.

21. Hart, H.L.A. 2012. The concept of law. Oxford: Oxford University Press.

22. Helfer, Christian. 1903. Henker-Studien. Archiv für Kulturgeschichte 46: 334-359.

23. Hillenbrand, Klaus. 2013. Berufswunsch Henker: Warum Männer im Nationalsozialismus Scharfrichter werden wollten. Frankfurt a.M.: Campus Verlag.

24. Hindelang, Götz. 2010. Einführung in die Sprechakttheorie: Sprechakte, Äußerungsformen, Sprechaktsequenzen. Berlin: De Gruyter.

25. Jefferies, Lesley, and Dan McIntyre. 2010. Stylistics. Cambridge: Cambridge University Press. 
26. Kellerhoff, Sven F. 2013. Warum ganz normale Männer Henker werden wollen. Welt. https://www. welt.de/geschichte/zweiter-weltkrieg/article119976906/Warum-ganz-normale-Maenner-Henker-werde n-wollten.html“ $\quad$ https://www.welt.de/geschichte/zweiter-weltkrieg/article119976906/Warum-ganznormale-Maenner-Henker-werden-wollten.html. Accessed 20 August 2020.

27. Koester, Almut. 2012. Building small specialised corpora. In The Routledge handbook of corpus linguistics, ed. Anne O'Keeffe and Michael McCarthy, 66-80. London: Routledge.

28. Kranert, Michael. 2019. Discourse and political culture: The language of the third way in Germany and the UK. Amsterdam: John Benjamins.

29. Kressel, Neil. 2002. Mass hate: The global rise of genocide and terror. Cambridge: Westview Press.

30. Langbein, Hermann. 2004. People in Auschwitz. Chapel Hill: University of North Carolina Press.

31. Mautner, Gerlinde. 2016. Discourse and management: Critical perspectives through the language lens. London: Palgrave.

32. Moon, Rosammund. 2012. What can a corpus tell us about lexis? In The Routledge handbook of corpus linguistics, ed. Anne O'Keeffe and Michael McCarthy, 197-212. London: Routledge.

33. Nelson, Mike. 2012. Building a written corpus: What are the basics? In The Routledge handbook of corpus linguistics, ed. Anne O'Keeffe and Michael McCarthy, 53-63. London: Routledge.

34. Pearl, Mike. 2015. What it's like to be a death row executioner in America. Voice Media Group. https ://www.vice.com/en_us/article/bnpxp5/how-do-you-get-a-job-as-an-executioner-in-america-526. Accessed 20 August 2020.

35. Reich, Wilhelm. 1946. The mass psychology of fascism. New York: The Orgone Institute Press.

36. Reichsstrafgesetzbuch 1935.

37. Reisigl, Martin, and Ruth Wodak. 2009. The discourse-historical approach. In Methods of critical discourse analysis, ed. Ruth Wodak and Michael Meyer, 87-121. London: Sage.

38. Reisigl, Martin, and Ruth Wodak. 2016. The discourse-historical approach. In Methods of critical discourse analysis, ed. Ruth Wodak and Michael Meyer, 21-61. London: Sage.

39. Reisigl, Martin. 2018. The discourse-historical approach. In The Routledge handbook of critical discourse analysis, ed. John Flowerdew and John Richardson, 44-59. London: Routledge.

40. Richtlinien für Scharfrichter 1937.

41. Rieger, Hans. 1967. Verurteilt zum Tod: Dokumentarbericht. Seelsorge im Gefängnis des Wiener Landgerichts 1942-1944. Wuppertal: Jugenddienst-Verlag.

42. Ringel, Erwin. 1990. Herrschaft und Knechtschaft: Symbolische Verflechtung aus individualpsychologischer Sicht. In Unterwerfung: Über den destruktiven Gehorsam, ed. Peter Huemer and Grete Schurz, 199-220. Wien: Paul Zsolnay.

43. Semelin, Jacques. 2005. Purify and destroy: The political uses of massacre and genocide. New York: Columbia University Press.

44. Spitzmüller, Jürgen, and Ingo H. Warnke. 2011. Diskurslinguistik: Eine Einführung in Theorien und Methoden der transtextuellen Sprachanalyse. Berlin: De Gruyter.

45. Stefanowitsch, Anatol. 2020. Corpus linguistics: A guide to the methodology. Berlin: Language Science Press.

46. The Guardian. 2015. Saudi Arabia advertises for eight new executioners as beheading rate soars. Guardian News \& Media. https://www.theguardian.com/world/2015/may/18/saudi-arabia-advertises -eight-new-executioners-beheadings-soar. Accessed 20 August 2020.

47. Thieberger, Nick, Anna Margetts, Stephen Morey, and Simon Musgrave. 2016. Assessing annotated corpora as research output. Australian Journal of Linguistics 36 (1): 1-21.

48. Thüringisches Hauptstaatsarchiv Weimar. $30 \mathrm{ff}$.

49. Toriida, Marie-Claude. 2016. Steps for creating a specialized corpus and developing an annotated frequency based vocabulary list. TESL Canada Journal 34 (11): 87-105.

50. United States Holocaust Memorial Museum. 2020. Ethical leadership: Causes and motivations. https:// www.ushmm.org/teach/teaching-materials/roles-of-individuals/ethical-leaders/background/causes-andmotivations. Accessed 20 August 2020.

51. Waltenbacher, Thomas. 2008. Zentrale Hinrichtungsstätten: Der Vollzug der Todesstrafe in Deutschland von 1937-1945. Scharfrichter im Dritten Reich. Berlin: Zwilling-Berlin.

52. Widdowson, Henry G. 1995. Discourse analysis: a critical view. Language and Literature 4 (3): $157-172$.

53. Widdowson, Henry G. 2004. Text, context, pretext: Critical issues in discourse analysis. Oxford: Blackwell. 
54. Wittgenstein, Ludwig. 2009. Philosophische Untersuchungen. Philosophical investigations. Translated by G. E. M Anscombe, P. M. S. Hacker and Joachim Schulte, Revised Fourth Edition. Chichester: Wiley.

55. Wodak, Ruth, and Michael Meyer. 2009. Critical discourse analysis: History, agenda, theory and methodology. In Methods of critical discourse analysis, ed. Ruth Wodak and Michael Meyer, 1-33. London: Sage.

56. Xiao, Richard, Tony McEnery, and Yukio Tono. 2006. Corpus-based language studies: An advanced resource book. London: Routledge.

Publisher's Note Springer Nature remains neutral with regard to jurisdictional claims in published maps and institutional affiliations. 